\title{
EFFICIENCY OF TOWN-REFUSE COMPOST, UREA AND THEIR COMBINATION IN WHEAT FERTILIZATION IN A SANDY SOIL
}

\author{
ABD EL-GHANI, M. M. AND M. A. NEGM
}

Soils, Water and Environment Research Inst., ARC, Giza

(Manuscript received 12 March 2009)

\begin{abstract}
A field experiment was conducted in Ali Moubarak Experimental Farm at El-Bostan Reclaimed Soil Sector $(100 \mathrm{~km}$ northwest of Cairo). The soil was none saline sandy soil irrigated with sprinkler system. The aim was to study the efficiency of application of town refuse compost, urea ( $46 \% \mathrm{~N}$ ) individually and in combination on wheat production along with the uptake of the nutrients $\mathrm{N}, \mathrm{P}, \mathrm{K}, \mathrm{Fe}, \mathrm{Mn}$ and $\mathrm{Zn}$. The used rates were 0,2 and 4 ton compost and 0,23 and $46 \mathrm{~kg} \mathrm{~N}$ as urea /fed.

The obtained results could be summarized as follows:

The application of compost at a rate of 4 ton compost/fed increased significantly grain uptake of both $\mathrm{P}$ and $\mathrm{Zn}$, straw yield, straw uptake of $\mathrm{Fe}$ and $\mathrm{Mn}$; and total uptake of $\mathrm{N}, \mathrm{Fe}$ and $\mathrm{Mn}$. At the rate of 2 ton compost/fed it significantly increased only straw and total uptake of $\mathrm{Mn}$ compared to the control .

Urea application at the rate of $46 \mathrm{~kg} \mathrm{~N} /$ fed was significantly increased grain yield, grain uptake of $\mathrm{N}$ and $\mathrm{P}$ and total $\mathrm{P}$ uptake, while the rate of $23 \mathrm{~kg} \mathrm{~N} /$ fed increased significantly grain N .

The combination of compost and urea caused significant increases in most of the studied parameters; proportionally correlated with increasing their rates of application.

The treatment of 4 ton compost/fed combined with $46 \mathrm{~kg}$ $\mathrm{N} / \mathrm{fed}$ as urea was significantly higher in grain yield, grain uptake of $\mathrm{N}, \mathrm{P}, \mathrm{K}, \mathrm{Mn}$ and $\mathrm{Zn}$, straw yield, straw uptake of $\mathrm{N}, \mathrm{P}, \mathrm{K}$, Fe and $\mathrm{Mn}$ over the control. This treatment was the highest treatment in grain yield, grain $\mathrm{N}, \mathrm{P}, \mathrm{Mn}$ and straw $\mathrm{Mn}$ compared to the other treatments.
\end{abstract}

\section{INTRODUCTION}

Satisfactory wheat production in Egypt is very important under the prevailing conditions. The newly reclaimed soils, including sandy ones, should be considered to help in increasing wheat production. Therefore, studying the factors raising productivity in sandy soils should be given more attention.

Application of organic manures and mineral fertilizers under modern irrigation systems are among these factors. Different sources of manures were investigated in wide trials, using wheat as a test crop.

In pot experiments, Amer et al. (1997) reported that town refuse composts collected from three regions increased $\mathrm{N}, \mathrm{P}, \mathrm{K}, \mathrm{Fe}, \mathrm{Zn}$ and $\mathrm{Cu}$ uptake by wheat when their application to a sandy soil increased from 1 to $2 \%$ of pot weight .Also, Mohamed (1999), used different rates of aerobic and anaerobic plant residue composts, obtained 
similar results concerning nutrients uptake in addition to an increase in plant dry matter when $4 \%$ per weight 6 months-aerobic compost combined with $20 \mathrm{~kg} \mathrm{~N} / \mathrm{fed}$ was used. Abdel-Aal et al. (2003) used complete organic fertilization or in combination with half the recommended mineral fertilizers, found that the most effective treatment resulted in the highest grain and straw yields was that received 10 to 20 ton of waterhyacint combined with 50 \% recommended NPK dose. Antoun et al. (1992), used 12 ton/fed town refuse compost corresponding about 4 ton organic $C$, at Ismaelia Res. Station Farm. They obtained $37.9 \%$ and $58.8 \%$ increases in grain yield and total $\mathrm{N}$ content in grains.

El-Sersawy et al. (1997) at Wadi Sedr, where $85 \%$ of the used calcareous sandy soil was sand, compared garbage compost with 20,40 or $60 \mathrm{~kg} \mathrm{~N} / \mathrm{fed}$ as ammonium nitrate. They achieved improvements in several soil physical parameters, microbial counts and NPK uptake as well, which were reflected on high grain and straw yields. El-Sharawy et al. (2003) at Ismaelia Res. Station Farm compared 20 ton/fed rice straw or cotton stalk composts with 100, 30 and $48 \mathrm{~kg}\left(\mathrm{~N}, \mathrm{P}_{2} \mathrm{O}_{5}\right.$ and $\mathrm{K}_{2} \mathrm{O} /$ fed., respectively) as inorganic fertilizers. According to them, DTPA soil extractable $\mathrm{Fe}, \mathrm{Mn}, \mathrm{Zn}$ and $\mathrm{Cu}$ after wheat or corn harvesting as well as grain yields and concentration of $\mathrm{N}, \mathrm{P}, \mathrm{K}, \mathrm{Fe}, \mathrm{Mn}, \mathrm{Zn}$ and $\mathrm{Cu}$ were significantly increased due to the application of such compost over the mineral application treatment.

Manna et al. (2003) at Bhopal Madhya Pradesh in India compared city garbage with the recommended doses of $\mathrm{N}, \mathrm{P}$ and $\mathrm{K}$ as inorganic fertilizers They pointed out that continuous application of compost increased micro-organism counts and enzyme activities compared with mineral fertilizers which sustained soil quality in terms of chemical and biological health. Mabrouk (2002) studied an organic (8 ton/fed of town refuse compost) and mineral $(8,15$ and $12 \mathrm{~kg} \mathrm{~N}, \mathrm{P}$ and $\mathrm{K} / \mathrm{fed}$.) fertilizers added to a sandy soil compared with the mentioned $\mathrm{N}, \mathrm{P}$, and $\mathrm{K}$ rates only. The organo mineral system produced higher peanut root, straw, seed yield, $N$ and $P$ uptake. Zeidan et al. (2005). At El-Nagah Village, south Al Tahrir Province compared 5, 10, 15 and $20 \mathrm{~m}^{3}$ of raw town refuses found that increasing application dose was more benefitial to soil and plants.

The objective of the current work was to find out the best treatment when town-refuse compost and urea were the applied sources to supply wheat with sufficient nutrients under sandy soil conditions. 


\section{MATERIALS AND METHODS}

A field experiment was conducted in the Experimental Farm at Ali Moubark village, El-Bostan Reclaimed Soil Sector (about $100 \mathrm{~km}$ northwest of Cairo). The soil analyses according to Black et al. (1965) were done as shown in Table 1.

The experimental soil was a sandy soil poor in its field capacity (F.C.), wilting point (W.P.), having less than $7 \%$ available water, low cation exchange capacity (C.E.C.) and low organic matter content (O.M.) .It had low total soluble salts (T.S.S.) where the soluble divalent $\mathrm{Ca}$ and $\mathrm{Mg}$ were dominating the soil solution. Most salts are chlorides and bicarbonates .

Table 1. Some main properties of the experimental site soil.

\begin{tabular}{|c|c|c|c|c|c|c|c|c|c|}
\hline \multicolumn{4}{|c|}{ Particle size distribution (\%) } & \multirow{2}{*}{ Texture } & \multirow{2}{*}{$\begin{array}{c}\mathrm{CaCO}_{3} \\
\%\end{array}$} & \multirow{2}{*}{$\begin{array}{c}\text { O.M. }{ }^{*} \\
\%\end{array}$} & \multirow{2}{*}{$\begin{array}{c}\text { F.C. } \\
\%\end{array}$} & \multirow{2}{*}{$\begin{array}{c}\text { W.P. } \\
\%\end{array}$} & \multirow{2}{*}{$\begin{array}{c}\text { C.E.C. } \\
\text { m.e./100gm }\end{array}$} \\
\hline C. sand & F. sand & Silt & Clay & & & & & & \\
\hline 66.5 & 29.2 & 2.2 & 2.1 & Sandy & 1.60 & 0.20 & 12.0 & 5.5 & 4.3 \\
\hline \multirow{2}{*}{$\begin{array}{c}\mathrm{PH} \\
(1: 2.5) \\
\end{array}$} & \multirow{2}{*}{$\begin{array}{l}\text { T.S.S. }^{* *} \\
(\%)\end{array}$} & \multicolumn{4}{|c|}{ Cations $\left(\mathrm{me} / \mathrm{l}^{* *}\right.$} & \multicolumn{4}{|c|}{ Anions $\left(\mathrm{me} / \mathrm{l}^{* *}\right.$} \\
\hline & & $\mathrm{Ca}^{2+}$ & $\mathrm{Mg}^{2+}$ & $\mathrm{Na}^{+}$ & $\mathrm{K}^{+}$ & $\mathrm{CO}_{3}{ }^{2-}$ & $\mathrm{HCO}_{3}$ & $\mathrm{Cl}^{-}$ & $\mathrm{SO}_{4}{ }^{2-}$ \\
\hline 7.90 & 0.049 & 3.0 & 1.8 & 2.1 & 0.6 & - & 2.7 & 4.0 & 0.8 \\
\hline
\end{tabular}

* Total combustible O.M. $\quad * * 1: 1$ soil-water extract.

The added compost was town refuses after aerobic composting for 2 months. The compost analyses (Table 2) were performed according to the methods described by Brunner and Wasmer (1978).

Table 2. Some main characteristics of used compost.

\begin{tabular}{|c|c|c|c|c|c|c|c|}
\hline $\begin{array}{l}\text { Bulk density } \\
\qquad\left(\mathrm{kg} / \mathrm{m}^{3}\right)\end{array}$ & $\begin{array}{c}\text { Moist. } \\
(\%)\end{array}$ & $\begin{array}{c}\mathrm{pH} \\
(1: 10) \\
\text { soil-water } \\
\text { susp. }\end{array}$ & \multicolumn{2}{|c|}{$\begin{array}{c}\text { EC (1:10 comp.-water } \\
\text { extract) } \\
\text { dS } / \mathrm{m}\end{array}$} & $\begin{array}{l}\text { Ash } \\
(\%)\end{array}$ & $\begin{array}{l}\text { O.M. } \\
(\%)\end{array}$ & $\begin{array}{l}\text { O.C. } \\
(\%)\end{array}$ \\
\hline 0.6 & 25 & 8.7 & & .95 & 55 & 38.5 & 22.33 \\
\hline Total & \multicolumn{7}{|c|}{ Total nutrient contents $\mathrm{mg} / \mathrm{kg}$ compost } \\
\hline $\mathrm{N} \%$ & $\mathrm{~N}\left(\mathrm{NH}_{4}\right)$ & $\mathrm{N}\left(\mathrm{NO}_{3}\right)$ & $\mathrm{P}$ & K & $\mathrm{Fe}$ & $\mathrm{Mn}$ & $\mathrm{Zn}$ \\
\hline 0.92 & 990 & 283 & 4500 & 12900 & 2450 & 660 & 264 \\
\hline
\end{tabular}

A split plot design was followed where main treatments were 0,2 and 4 tons of compost/fed. The sub-main treatments were 0,30 and $60 \mathrm{~kg}$ urea/fed. Each treatment was replicated four times.The replicate was of $6 \times 7 \mathrm{~m}^{2}$ size. The compost was of fine homogeneous material, having a light brown colour, which were thoroughly mixed with the $20 \mathrm{~cm}$ surface layer of soil on the $31^{\text {st }}$ of October 2003. 
On the $14^{\text {th }}$ of November 2003, wheat (Triticum aestivum) Variety Sakha 69 was planted using a sprinkler irrigation system. Dipotassium phosphate (17.8 \% P and 44.8 $\% \mathrm{~K}$ ) was added at a rate of $36.5 \mathrm{~kg} / \mathrm{fed}$ through fertigation. Nitrogen fertilizer as urea was added top dressing at a rate of either 23 or $46 \mathrm{~kg} \mathrm{~N}$ in a form of urea (46\% N) in three equal doses after 4, 6 and 8 weeks of planting. On the $5^{\text {th }}$ of May 2004, crop was harvested. Fresh weight of plants collected from each plot was recorded with 1 $\mathrm{m}^{2}$ being left in the middle which was harvested on the second day as a study sample.

The studied sample was separated to grains and straw, fresh and $70 \mathrm{C}$ oven dried weights were recorded and prepared for $\mathrm{N}, \mathrm{P}, \mathrm{K}, \mathrm{Fe}, \mathrm{Mn}$ and $\mathrm{Zn}$ determinations after Chapman and Pratt (1961). The statistical analyses of the obtained data were performed according to Petersen (1976).

Soil available macronutrients ( $\mathrm{N}, \mathrm{P}$ and $\mathrm{K}$ ) were determined using the methods described by Black et al. (1965). Soil available micronutrients (Fe, Mn and $\mathrm{Zn}$ ) were determined using Diethyline triamin pentaacetic acid (DTPA) extract as described by Lindsay and Norvell (1978); Table 5 .

It may be worthy to mention that efficiency of a material to supply with certain element is calculated as follows:

A $\mathrm{kg} / \mathrm{fed}=$ The recovery of the certain element by plants treated with that material - the recovery by untreated plants.

$\mathrm{B} \mathrm{kg} / \mathrm{fed}=$ The added quantity of that elements from the added material.

$$
\text { Efficiency } \%=\frac{A \times 100}{B}
$$

\section{RESULTS AND DISCUSSION}

\section{Wheat yield and harvest index}

Table 3 presents data of grain yield, straw yield and their harvest index. Regarding grain yield, application of $46 \mathrm{~kg} \mathrm{~N} / \mathrm{fed}$ as urea increased grain yield significantly over the control. On the other hand, all compost and urea combinations treatments increased grain yield significantly over the control. The most effective treatment was that of 4 ton compost/fed and $46 \mathrm{~kg} \mathrm{~N} /$ fed as urea.

As for straw, 4 ton compost/fed increased significantly the yield over the control, wheather it was applied alone or in combination with any of the two urea rates while application of urea alone had no significant effect on straw yield . Response of wheat grain and/or straw yields to manure-mineral $\mathrm{N}$ applications in sandy soil was also found by Antoun et al. (1992), El-Sersawy (1997), Abdel-Aal et al. (2003) and El-Sharawy et al. (2003). 
With respect to harvest index (the percentage of grains to whole plant), the application of $46 \mathrm{~kg} \mathrm{~N} / \mathrm{fed}$ as urea increased this parameter significantly compared to the treatment of 2 ton compost/fed, 2 ton compost/fed $+23 \mathrm{~kg} \mathrm{~N} / \mathrm{fed}$ as urea or 4 ton compost/fed $+23 \mathrm{~kg} \mathrm{~N} / \mathrm{fed}$ as urea. On the other hand, no significant difference was found between the values of the $46 \mathrm{~kg} \mathrm{~N} / \mathrm{fed}$ and the rest of the treatments.This result could be attributed to the different relative increases in grain and straw yields compared to each other.

Table 3. Effect of different rates of compost and $\mathrm{N}$ (as urea) on wheat yields and harvest index.

\begin{tabular}{|c|c|c|c|c|c|c|}
\hline \multirow{2}{*}{$\underset{\Phi}{\underline{\Phi}}$} & \multirow{2}{*}{ 壼 } & \multirow{2}{*}{$\begin{array}{c}\mathrm{N} \text { rates } \\
(\mathrm{kg} / \mathrm{fed})\end{array}$} & \multicolumn{3}{|c|}{ Compost (ton/fed) } & \multirow{2}{*}{$\begin{array}{l}\text { L.S.D. } \\
(0.05)\end{array}$} \\
\hline & & & 0 & 2 & 4 & \\
\hline \multirow{3}{*}{ 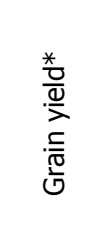 } & \multirow{3}{*}{ 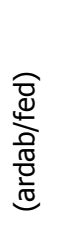 } & 0 & 5.27 & 5.58 & 5.35 & \multirow{3}{*}{1.49} \\
\hline & & 23 & 5.82 & 7.02 & 7.18 & \\
\hline & & 46 & 7.20 & 7.28 & 9.30 & \\
\hline \multirow{3}{*}{$\begin{array}{l}\frac{0}{0} \\
\frac{0}{2} \\
3 \\
\text { 竞 } \\
\text { 心 }\end{array}$} & \multirow{3}{*}{ 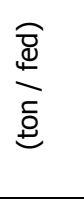 } & 0 & 1.41 & 1.91 & 2.26 & \multirow{3}{*}{0.74} \\
\hline & & 23 & 1.69 & 2.35 & 2.90 & \\
\hline & & 46 & 1.77 & 2.13 & 2.90 & \\
\hline \multirow{3}{*}{ 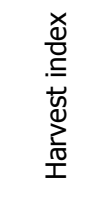 } & \multirow{3}{*}{$\stackrel{0}{0}$} & 0 & 34.45 & 31.55 & 33.30 & \multirow{3}{*}{7.33} \\
\hline & & 23 & 34.27 & 30.97 & 28.02 & \\
\hline & & 46 & 39.32 & 37.25 & 32.76 & \\
\hline
\end{tabular}

*Ardab of wheat grains $=150 \mathrm{~kg}$.

\section{Nutrient uptake}

Macro and micro nutrients uptake by plants are presented in Table 4. It may be noticed that amounts of $\mathrm{N}, \mathrm{P}, \mathrm{K}, \mathrm{Fe}, \mathrm{Mn}$ and $\mathrm{Zn}$ in either grains or straw increased by application of compost and urea individually or in combination by any of the used rates. These increases were insignificant in case of Fe in grains, $\mathrm{P}$ and $\mathrm{Zn}$ in straw and Zn uptake by whole plant . 


\subsection{Nitrogen}

In general, the uptake of $\mathrm{N}$ by grains, straw and whole plant responded positively to the town refuse compost applications. A higher significant difference in uptake of $\mathrm{N}$ in grains was found between the 4 ton compost/fed rate of compost and the control, while there were no significant difference between the treatments in the case of $\mathrm{N}$ uptake either in straw or in the whole plant. The same findings were obtained by Amer et al. (1997), El- Sersawy (1997), Abdel-Aal et al. (2003) and ElSharawy et al. (2003).

Regarding application of urea, it was found that it has the same trend where there is a positive respond to urea application. Both 23 and $46 \mathrm{~kg} \mathrm{~N} /$ fed rates produced significant differences in the $\mathrm{N}$ uptake by grains compared with the control. Urea application did not increase straw $\mathrm{N}$ or total $\mathrm{N}$ uptake significantly compared to the control. In all cases, combination between the 4 ton compost/fed rate of townrefuse compost $+46 \mathrm{~kg} \mathrm{~N}$ urea/fed gave the highest effect on $\mathrm{N}$ uptake being about 3 times as that in control plants. Significant differences between the different treatments can be observed from Table 4.

Efficiency of town refuse compost without urea association to wheat was the same at $56 \%$ indicating that $\mathrm{N}$ release from each 2 or 4 ton compost/fed rate was proportionate with total $\mathrm{N}$ uptake by plants as a whole. Efficiency of compost at any rate associated with urea was declined in spite of their pronounced effect in increasing $\mathrm{N}$ uptake significantly.

\subsection{Phosphorus}

Application of 4 ton compost/fed or $46 \mathrm{~kg} \mathrm{~N} /$ fed was found to be significantly the highest treatments regarding $P$ uptake which was about 3.5 and 2.5 of its uptake in untreated grains and whole plants, respectively. In the case of straw, combination of compost and urea did not give significant effects on P uptake. El-Sersawy (1997) and Manna et al (2003) in their studies showed that there is a remarkable effect of urea application on $\mathrm{P}$ uptake by wheat plants. They mentioned that this may be due to that urea enhancing wheat root to absorb more nutrient and translocate it to grains than that those unfertilized with urea.

Efficiency of the used town-refuse compost individually to supply wheat with $\mathrm{P}$ was relatively low (13\%) regardless of its added rate. Urea application increased compost efficiency for $P$ uptake especially the rate of $46 \mathrm{~kg} \mathrm{~N} / \mathrm{fed}$ which increased that efficiency one and half time more than the treatments receiving compost only.

\subsection{Potassium}

Amount of $\mathrm{K}$ in grains was low compared to that in straw with a ratio about 1 : 5. Generally, applications of town- refuses compost or urea individually did not 
increased $\mathrm{K}$ uptake significantly. On the other hand, combination of 4 ton compost/fed $+46 \mathrm{~kg} \mathrm{~N} / \mathrm{fed}$ as urea raised $\mathrm{K}$ uptake in grains, straw and whole plant over the control significantly being more than 1.5, 2.5 and 2 times their amounts in the control, respectively. In case of straw $\mathrm{K}$ and total uptake the combinations of 2 ton compost/fed +23 or $46 \mathrm{~kg} \mathrm{~N} / \mathrm{fed}$ and 4 ton compost/fed $+23 \mathrm{~kg} \mathrm{~N} / \mathrm{fed}$ caused significant increases over the control. These results were in agreement with ElSersawy (1997), Abdel-Aal et al. (2003) and El Sharawy et al. (2003).

Regarding the efficiency of the used compost for supplying wheat plants with $K$, in case of adding 2 ton compost/fed alone its efficiency was relatively higher than that of both 4 ton compost/fed alone and its combination with urea. On the other hand, adding 4 ton compost/fed $+46 \mathrm{~kg} \mathrm{~N} /$ fed as urea increased the efficiency than their individual application by about $33 \%$.

\subsection{Iron}

Application of urea alone did not increase Fe uptake significantly while the combination of the 4 ton compost/fed and $46 \mathrm{~kg} \mathrm{~N} / \mathrm{fed}$ as urea increased it significantly over the individual applications of 23 and $46 \mathrm{~kg} \mathrm{~N} / \mathrm{fed}$ as urea and 2 ton compost/fed causing about 2.5 times as that in the control plants.

Efficiency of compost for Fe supply to wheat plants was stable in any of the application rates whether combined with urea or not. Efficiency was between 11 and $13 \%$. which is considered relatively low.

\subsection{Manganese}

Individual applications of 2 and 4 ton compost/fed or $46 \mathrm{~kg} \mathrm{~N} / \mathrm{fed}$ as urea produced significant increases in straw $\mathrm{Mn}$ uptake and total $\mathrm{Mn}$ uptake over the control; while $\mathrm{Mn}$ amount in grains did not affected by application of compost or urea individually. At the same time, the treatment 4 ton compost/fed $+46 \mathrm{~kg} \mathrm{~N} / \mathrm{fed}$ as urea raised significantly $\mathrm{Mn}$ amounts in grains and straw over the other treatments.

Efficiency of compost application to supply wheat with Mn was higher in case of the rate of 2 ton compost/fed than that in case of 4 ton compost/fed rate with about two folds ice. Application of $23 \mathrm{~kg} \mathrm{~N} / \mathrm{fed}$ as urea raised each of the two used compost rate efficiencies. The efficiency values which ranged from $14 \%$ to $39 \%$ emphasized the low ability of wheat to absorb more Mn but urea could encourage that selective trend.

\subsection{Zinc}

Applications of 4 ton compost/fed with 23 or $46 \mathrm{~kg} \mathrm{~N} /$ fed as urea increased significantly Zn uptake by grains over the control, the two studied factors were not effective on straw $\mathrm{Zn}$ or total $\mathrm{Zn}$ uptake. 
Efficiency of compost on Zn absorption was about 3 times higher when using 2 ton compost/fed compared to that of 4 ton compost/fed rate whether the application were alone or combined with $23 \mathrm{~kg} \mathrm{~N} /$ fed. It could be indicated that wheat plant followed more stable trend in $\mathrm{Zn}$ absorption than in $\mathrm{Mn}$.

Generally, as for Fe, $\mathrm{Mn}$ and $\mathrm{Zn}$ uptake by wheat under such condition, organic additions used in the studies of Abdel-Aal et al. (2003) and El-Sharawy et al. (2003) increased the uptake of these elements .

\section{Changes in some soil properties}

Table 5 presents the data of soil analysis at wheat harvesting. Salinity in the studied upper $30 \mathrm{~cm}$ layer was not affected with any of the applications. On the other hand, cation exchange capacity (C.E.C.) increased generally by wheat cultivation with about $8.24 \%$ of the initial value. This could be due to the presence of some organic residues of wheat roots as well as compost residues. It could be concluded that there was no pronounced effect of compost or urea applications on C.E.C.

Table 5. Some soil properties at wheat harvesting as affected with different town-rfuse compost and urea rates of application.

\begin{tabular}{|c|c|c|c|c|c|c|c|c|c|c|}
\hline \multirow{2}{*}{ Determ. } & \multirow{2}{*}{$\mathrm{kg} / \mathrm{fed}$} & \multicolumn{3}{|c|}{0 compost } & \multicolumn{3}{|c|}{2 ton compost/fed } & \multicolumn{3}{|c|}{4 ton compost/fed } \\
\hline & & 0 & 23 & 46 & 0 & 23 & 46 & 0 & 23 & 46 \\
\hline T.S.S((\% & \multirow{9}{*}{ 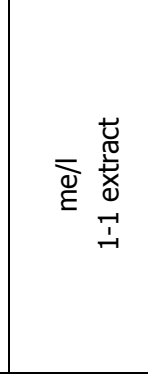 } & 0.097 & 0.099 & 0.090 & 0.110 & 0.094 & 0.089 & 0.120 & 0.105 & 0.093 \\
\hline $\mathrm{Ca}^{2+}$ & & 5.00 & 5.00 & 7.00 & 7.60 & 4.50 & 6.00 & 9.00 & 7.50 & 5.50 \\
\hline $\mathrm{Mg}^{2+}$ & & 3.30 & 3.90 & 3.30 & 3.30 & 4.10 & 4.00 & 4.00 & 3.90 & 5.60 \\
\hline $\mathrm{Na}^{+}$ & & 4.30 & 4.30 & 2.50 & 4.50 & 4.00 & 2.70 & 4.00 & 3.50 & 2.30 \\
\hline $\mathrm{K}^{+}$ & & 2.50 & 3.20 & 1.10 & 2.40 & 2.10 & 1.20 & 1.70 & 1.50 & 1.10 \\
\hline $\mathrm{CO}_{3}^{2-}$ & & - & - & - & - & - & - & - & - & - \\
\hline $\mathrm{HCO}_{3}^{-}$ & & 1.00 & 1.00 & 1.00 & 1.50 & 1.00 & 1.00 & 2.00 & 1.50 & 1.50 \\
\hline $\mathrm{Cl}^{-}$ & & 2.80 & 2.80 & 2.80 & 2.80 & 2.80 & 2.80 & 3.00 & 3.00 & 2.80 \\
\hline $\mathrm{SO}_{4}{ }^{2-}$ & & 11.30 & 11.70 & 10.20 & 12.90 & 10.9 & 10.20 & 13.70 & 11.9 & 11.20 \\
\hline $\mathrm{ExCa}^{2+}+\mathrm{Mg}^{2+}$ & $\overline{\bar{c}}$ & 4.30 & 4.29 & 4.10 & 4.35 & 4.20 & 4.10 & 4.50 & 4.30 & 4.10 \\
\hline Exch. $\mathrm{Na}^{+}$ & 品 & 0.73 & 0.71 & 0.73 & 0.75 & 0.77 & 0.71 & 0.73 & 0.73 & 0.71 \\
\hline Exch. $\mathrm{K}^{+}$ & $\overline{\mathrm{O}}$ & 0.18 & 0.17 & 0.15 & 0.18 & 0.20 & 0.16 & 0.17 & 0.17 & 0.15 \\
\hline CEC & u & 5.21 & 5.17 & 4.98 & 5.28 & 5.17 & 4.97 & 5.40 & 5.20 & 4.96 \\
\hline \multicolumn{2}{|c|}{ pH (1-2.5susp.) } & 8.15 & 8.26 & 8.73 & 8.52 & 7.96 & 8.33 & 8.36 & 8.62 & 8.58 \\
\hline O.M. $(*)$ & $\%$ & 0.32 & 0.31 & 0.31 & 0.31 & 0.30 & 0.30 & 0.30 & 0.30 & 0.28 \\
\hline O.M.(**) & $\%$ & 0.100 & 0.140 & 0.145 & 0.123 & 0.137 & 0.134 & 0.168 & 0.165 & 0.160 \\
\hline Total N & $\%$ & 0.017 & 0.019 & 0.028 & 0.016 & 0.019 & 0.044 & 0.028 & 0.037 & 0.048 \\
\hline \multicolumn{2}{|l|}{$\mathrm{C} / \mathrm{N}(1)$} & 10.92 & 9.46 & 6.42 & 11.24 & 9.16 & 3.95 & 6.21 & 4.70 & 3.38 \\
\hline \multicolumn{2}{|l|}{$\mathrm{C} / \mathrm{N}(2)$} & 3.41 & 4.27 & 3.00 & 4.46 & 4.18 & 1.77 & 3.48 & 2.59 & 1.93 \\
\hline \multirow{6}{*}{ 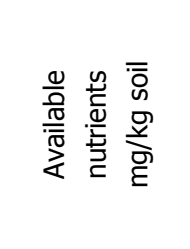 } & $\mathrm{N}$ & 7.02 & 16.32 & 38.82 & 9.12 & 16.42 & 45.62 & 14.42 & 22.12 & 49.12 \\
\hline & $P$ & 5.40 & 6.00 & 6.30 & 4.50 & 4.90 & 5.50 & 3.90 & 4.10 & 4.30 \\
\hline & K & 121.9 & 121.9 & 110.8 & 121.9 & 121.9 & 121.9 & 121.9 & 121.9 & 99.7 \\
\hline & $\mathrm{Fe}$ & 3.13 & 3.36 & 3.31 & 3.62 & 3.67 & 3.63 & 2.72 & 2.99 & 3.06 \\
\hline & $\mathrm{Mn}$ & 0.112 & 0.144 & 0.196 & 0.196 & 0.212 & 0.226 & 0.200 & 0.256 & 0.260 \\
\hline & $\mathrm{Zn}$ & 0.189 & 00174 & 0.125 & 0.186 & 0.124 & 0.078 & 0.152 & 0.151 & 0.142 \\
\hline
\end{tabular}

$\left(^{*}\right)$ Total combustible O.M.

$\left.{ }^{(* *}\right)$ Walkely \& Black oxidizable O.M. method, (after Black et al. 1965). 
Soil $\mathrm{pH}$ values tended to be more alkaline especially in presence of urea without applied compost. Organic matter content was determined as a total combustible content and oxidizable one to compare each content to the other. The combustible content was twice to three times of the oxidizable amount. The oxidizable portion increased proportionally by compost applications. Urea application increased it also but slightly.

Total $\mathrm{N}$ increased markedly by increasing application rates of compost and slightly/or urea. This finding could explain the low efficiency of both for $\mathrm{N}$ recovery where considerable amounts of $\mathrm{N}$ were still remained in soil after the cultivation season.

As for $\mathrm{C} / \mathrm{N}$ ratio, each of compost and urea application narrowed it due to their effect on increasing total $\mathrm{N}$ content. The ratio calculated on the basis of organic combustible was most descriptive referring to the ordinary values of such sandy soils.

Abdel-Aal et al. (2003), El-Sharawy et al. (2003) and Manna et al. (2003), found that their used sandy soils had been improved by their organic additions. Their results are in agreemend with our findings (C. E. C. and O. M.).

In general it could be concluded that :

1 - Application of town-refuse compost increased proportionally the available form of $\mathrm{N}$ and $\mathrm{Mn}$ but decreased available $\mathrm{P}$ and $\mathrm{Zn}$. There were no pronounced effects on K and Fe. Similar results were obtained by Mohamed (1999), Abdel-Aal et al. (2003) and El-Sharawy et al. (2003).

2 - Urea application resulted in proportional increases in available N, P, Fe and $\mathrm{Mn}$ with the effect being reversely on $\mathrm{Zn}$ and somewhat on $\mathrm{K}$.

3 - The interaction effect of the two used factors was clear only in case of soil $\mathrm{N}$ where combination of 4 ton compost/fed $+46 \mathrm{~kg} \mathrm{~N} /$ fed resulted in their highest values.

\section{REFERENCES}

1. Abdel- Aal, Sh. I. , M. A. Abdel-Hamid, S. A. Ismaiel, A. Abd El-Fattah and S. S. Taalab. 2003. Effect of organic farming practice on nutrient availability and wheat yield grown on Torripsamments. Egypt. J. Soil Sci. 43 (1) : 47 - 62.

2. Amer, A. A., M. A. Badawi and A. A. Banna. 1997. Effect of organic manuring on wheat plants grown in sandy soil. Annals. Agric. Sci. Ain-shams Univ. Cairo. 42 (1) : 107 - 116.

3. Antoun, G. G., F. M. Abdalla and E. M. Gaafar. 1992. Effect of increasing amounts of organic manure on wheat yield. Egypt. J. Agric. Res. 70 (1): 1 - 8. 
4. Black, C. A. (ed.), D. O. Evans, L. E. Ensmingers, J. L. White, F. E. Clark and R. C. Dionouer. 1965. Methods of Soil Analysis. Amer. Soc. Agronomy, Inc. Madison, Wisconsin, U.S.A.

5. Brunner, P. H. and H. R. Wasmer. 1978. Methods of Analysis of Sewage Sludge, Solid Wastes and Compost. WHO International Reference Center for Wastes Disposal (H-8600) Dulendrof, Switzerland.

6. Chapman, H. D. and P. F. Pratt. 1961. Methods of Analysis of Soil, Plant and Waters. Division of Agron. Science, Univ. Calif

7. El-Sersawy, M. M., Bauthaina F. Abd El-Ghany, K. W. Khalil and S. Y. Awadalla. 1997. Interaction between organic manure mixtures, applied $\mathrm{N}$-level and biofertilization on calcareous soil properties and wheat production in Wadi Sudr, South Sinai. Egypt. J. Soil Sci.. 37 (3) : 367 - 397.

8. El-Sharawy, M. A. O., M. A. Aziz and Laila K. M. Ali . 2003. Effect of application of plant residue composts on some soil properties and yield of wheat and corn plants. Egypt. J. Soil Sci. 43 (3) : 421 - 434.

9. Lindsay, W. L. and W. A. Norvell. 1978. Development of DTPA soil test for Zn, Fe and Cu. Soil Sci. Soc. Am. J. 42 : 421 - 428.

10. Mabrouk, S. S. 2002. Response of some peanut cultivars to bio and organomineral fertilization Zagazig J. Agric. Res. 29 (6) : 2071 - 2071.

11. Manna, M. C., P. K. Ghosh and T. K. Ganguly . 2003. Comparative performance of four sources of enriched phospho-compost and inorganic fertilizer application on yield, uptake of nutrients and biological activity of soil under soybean-wheat rotation. J. Food. Agric. Environ. 6 (2) : 203 - 208.

12. Mohamed, M. M. H. 1999. Organic Refuses Composted by Microorganisms and Their Effect on the Availability of Some Nutrients in Newly Reclaimed Soils. Ph. D. Thesis, Faculty of Agric. Moshtohor, Zagazig University, Benha Branch.

13. Peterson, R. G. 1976. Experimental Design for Agricultural Research in Developing Areas. Inc. Corrallie, Oregon, U.S.A.

14. Zeidan, M. S., M. Hozayn and M. F. El-Karamany. 2005. Effect of different organic fertilizer sources and levels on growth and yield of wheat (Triticum aestivum $\mathrm{L}$ ) in sandy soil. The $3^{\text {rd }}$ Sci. Conf. of the Agricultural and Biological Division, National Research Center (NRC), April 23 - 24, 2005 Cairo, Egypt. Egypt. J Agric. Res., (Special essay of NRC Conf.): 2 (2). 


\title{
كفاعة مكمورة قمامة المدن و اليوريا فى تسميد نبات القمح \\ المزروع بأرض رملية
}

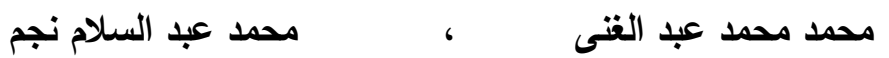 \\ معهة بحوث الأراضى والمباه والبيئة - مركز البحوث الزراعية - الجبية
}

أجريت تجربـة حقلية بمزرعـة على مبـارك التجريبيـة بقطاع الاراضـى المستصلحة بالبستان

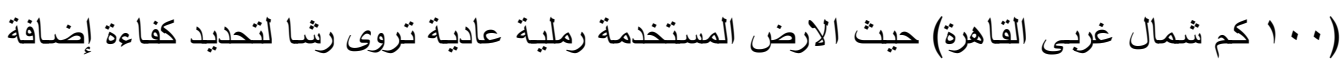

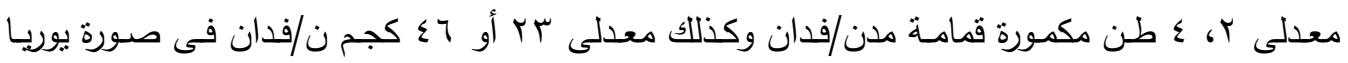

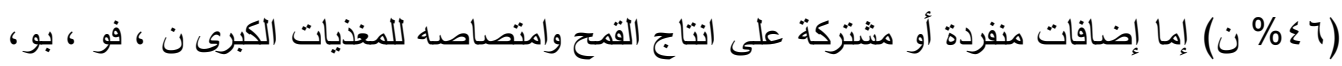
والصغرى ح ، من ، خ خ.

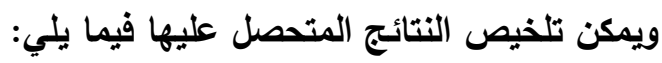

أثرت إضـافة معدل؛ طن من المكمور معنويا فى زيادة الممنص من الفوسفور والخارصين

وكذلك محصـول القش والممتص بـه من الحديد والمنجنيز والممتص الكلى مـن النيتروجين و الحديد

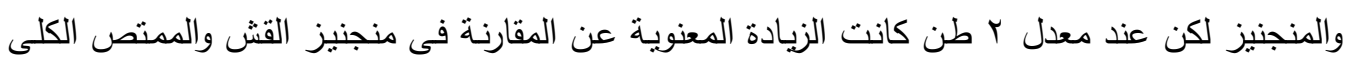

وأدت إضافة معدل \؟ كجم ن فى صورة يوريا لزيادة معنوية فى محصول الحبوب والممتص بـه

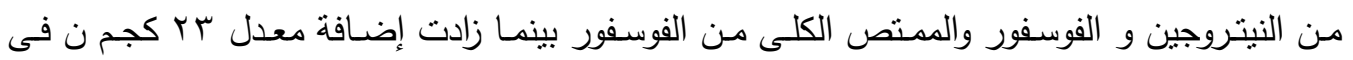
صورة يوريا الممتص من النيتروجين فى الحبوب معنويا.

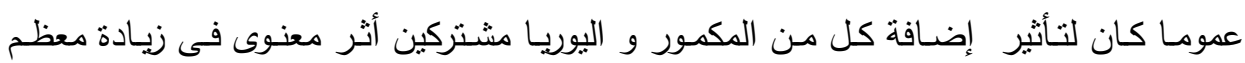

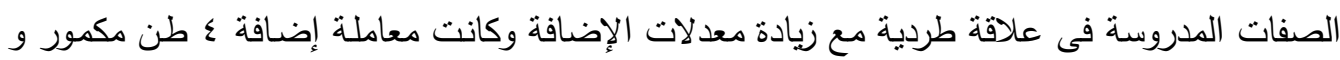

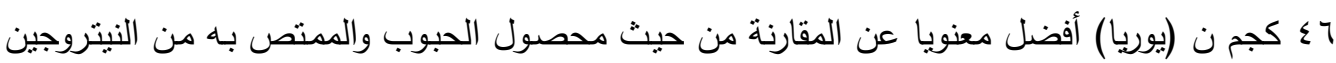
و الفوسفور والبوتاسيوم والمنجنيز والخارصين و محصول القش والممتص به من النيتروجين و الفوسفور

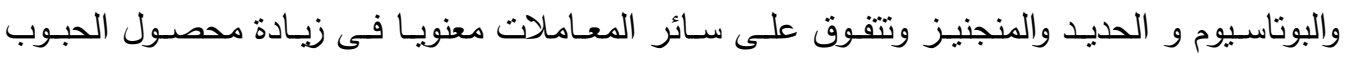
والممتص به من النيتروجين و الفوسفور والمنجنيز والممتص بالقش من المنجنيز • 